Bolm. Zool., Univ. S. Paulo

5: $19-29,1980$

\title{
STUDIES ON SOME SPECIFIC BIOLOGICAL AND TEMPORAL FACTORS AFFECTING MATING AND/OR OVIPOSITION IN TRIBOLIUM CASTANEUM (HBST.) ) COLEOPTERA: TENEBRIONIDAE
}

\author{
R. Narayan Singh \& S. S. Krishna \\ Entomology Laboratory, Department of Zoology, \\ University of Gorakhpur, Gorakhpur - 273001, U.P., \\ India. \\ (Recebido em 10.01.1979)
}

\section{RESUMO}

Machos a fêmeas de Tribolium castaneum, recérn-eclodidos, parearam para copulação durante os dois períodos de 8 horas (octetos) (de 6:00 até 14:00 ou de 14:00 até 22:00 hs) de um ciclo diário de 24 horas e começaram a oviposição no 1.0 ou 2.0 dia após o pareamento. O casal monogâmico, geralmente perfaz múltiplas copulaçōes (na maioria das vezes, $3 \mathrm{cu}$ 4) durante aqueles periodos. O coito é sempre curto e dura de 25 a 208 segundos. Diferenças em idade de machos e fêmeas na época da copulação produzem variaçōes interessantes nos padrōes de oviposição neste inseto. Em todas as situaçōes experimentais estudadas, nāo foi afetada a viabilidade de $100 \%$ dos ovos postos pelas fêmeas.

\section{ABSTRACT}

Freshly emerged males and females of Tribolium castaneum coupled for mating during any of two 8-hour periods (octets) (6.00 through 14.00 or 14.00 through 22.00) of a 24-hour daily cycle commence oviposition on the lst or 2nd day following pairing. The two sexes constituting a single pair generally perform multiple matings (in most instances 3 or 4 times) during any of these octets. Coitus sessions between males and females are always brief and range from 25 to 208 seconds. Differences in age of males and females at the time of their mating produce interesting variations in the ovipositional patterns in this insect without affecting the $100 \%$ viability of eggs laid by the females in all experimental situations studied. 


\section{INTRODUCTION}

Our knowledge concerning certain aspects of reproduction in the red flour beetle, Tribolium castaneum (Hbst.) - a major cosmopolitan pest of flour, meal and different kinds of stored cereal products (KINGS \& DAWSON, 1977) - is mostly derived from already available accounts (GOOD, 1933; PARK \& DAVIS, 1945; BIRCH ET AL, 1951; KHALIFA \& BADAWY, 1955 a \& b; KRISHNA, 1959; SCHLAGER, 1960; DAWSON, 1964; ERDMAN, 1964; APPLEBAUM \& LUBIN, 1967; VARDELL \& BROWER, 1976; HAMALAINEN \& LOSCHIAVO, 1977) and from the latest information contained in a forthcoming publication (SINGH \& KRISHNA, 1981). However, the contributions made by all these workers hardly dwell upon the influence of age of both sexes (although DAWSON (1964) and VARDELL \& BROWER (1976) have briefly reported some of their findings concerning this issue) or time of the 24 - hour daily cycle on the female's mating and/or her subsequent egg laying. An effort is, therefore, made in the present program of research to investigate into these areas of study in the reproductive biology of this pest and the results obtained are included in this communication. Hopefully, the information contained herein will, besides filling up the lacunae in our understanding, generate newer insights into our comprehension of the behavioral and physiological principles associated with the breeding potential of $\mathbf{T}$. castaneum on cereal or other stored products.

\section{MATERIAI، \& METHODS}

Ten freshly-laid eggs, taken from a laboratory stock culture of these beetles maintained on whole wheat flour containing $5 \%$ powdered yeast (B.P.C. product, Alembic Chemical Works Co. Ltd., Baroda, India) at $30^{\circ}-32^{\circ} \mathrm{C}$ and r.h. varying between 90 and $100 \%$, were placed together inside a glass vial (30 mm diameter; $100 \mathrm{~mm}$ height) filled with adequate quantity of freshly prepared culture diet for hatching and postembryonic development up to pupal stage. The top end of the glass vial was always covered with a piece of muslin cloth fastened by rubber strings. The food provided to the growing larvae inside the vials were changed once a week.

As soon as the larvae metamorphosed into pupae, they were separated on the basis of clearly manifested sexual dimorphism on their terminal body segments (GOOD, 1933) into male and female members and arranged in several distinct lots, each consisting of 5 pupae of the same sex, for emergence into adults.

To assess the mating potential between males and females of differing ages and the subsequent reproductive performance of these females in terms of their egg output and fertility of laid eggs, independent experiments were arranged wherein in a single test one freshly eclosed male or female beetle was always paired for mating with an adult individual of the opposite sex belonging to one of the following ages (expressed in days counted from emergence): $0,4,9,15$ and 20 . Males and females of these different combinations of ages were always held in couples for the first 5 days (calculated from pairing day) only 
of a 20-day experimental period. The reason for limiting the association of the sexes to this short duration was based on the assumption of existence of behavioral and physiological similarities concerning activity of sex pheromones in relation to age between these beetles and their allied species $T$. confusum (CEALLACHAIN \& RYAN, 1977). However, with a view to determine the influence of the continuos presence of male with female right from the pairing day and all through the specified test period on the egg yield by the female, an additional experimental series was arranged with newborn individuals of both sexes given the opportunity to remain together for the entire duration of observation period.

Frequency and duration of mating in $\mathbf{T}$. castaneum during a part of the 24-hour daily time cycle were also determined. Tests designed to study these aspects were started with separately constituted single pairs of newly emerged males and females held together for one of the two 8-hour periods (6.00 through 14.00-first octet, or 14.00 through 22.00 - second octet) on the first day and continued witl the same lots similary for 9 successive days. For the remaining part of the normal day - night rhythm, when the sexes were not paired, they were however allowed to enjoy the company of each other only through a metallic wire mesh partition installed between the insects in a manner basically identical to that reported for Earias fabia (SHAHI \& KRISHNA, 1978) so as to provide separate compartments for each individual. Continuous observation was made during each 8 - hour period every experimental day when the insects were in paired state to record the number of matings and the length of each copulatory act per female.

All pairing, mating and individual oviposition trials outlined above were performed in small glass vials (15 mm diameter; $50 \mathrm{~mm}$ height) covered as described earlier and kept at the same temperature and r.h. selected for maintenance of stock culture. Adequate amount of whole wheat flour supplemented with $5 \%$ powdered yeast was provided to the beetles housed in each vial at all times except when observations concerning mating frequency and the duration of coitus between males and females were to be noted.

Oviposition in the first category of experiments, though monitored daily, was accounted as sets of egg yield values computed for each 5 - day term (refered here as a pentad phase) (relating to days following pairing) of the 20 - day test period. The hatchability of the eggs laid by these females was also ascertained.

All trials concerning this investigation were adequately replicated and the quantitative information obtained here meaningfully presented below.

\section{RESULTS \& DISCUSSION}

Newborn females when paired for mating with freshly emerged males showed an egg laying trend in which the oviposition peaked during the 2nd pentad phase of the 20 - day experimental period (Fig. 1). This egg output pattern remained more or less unchanged regard- 


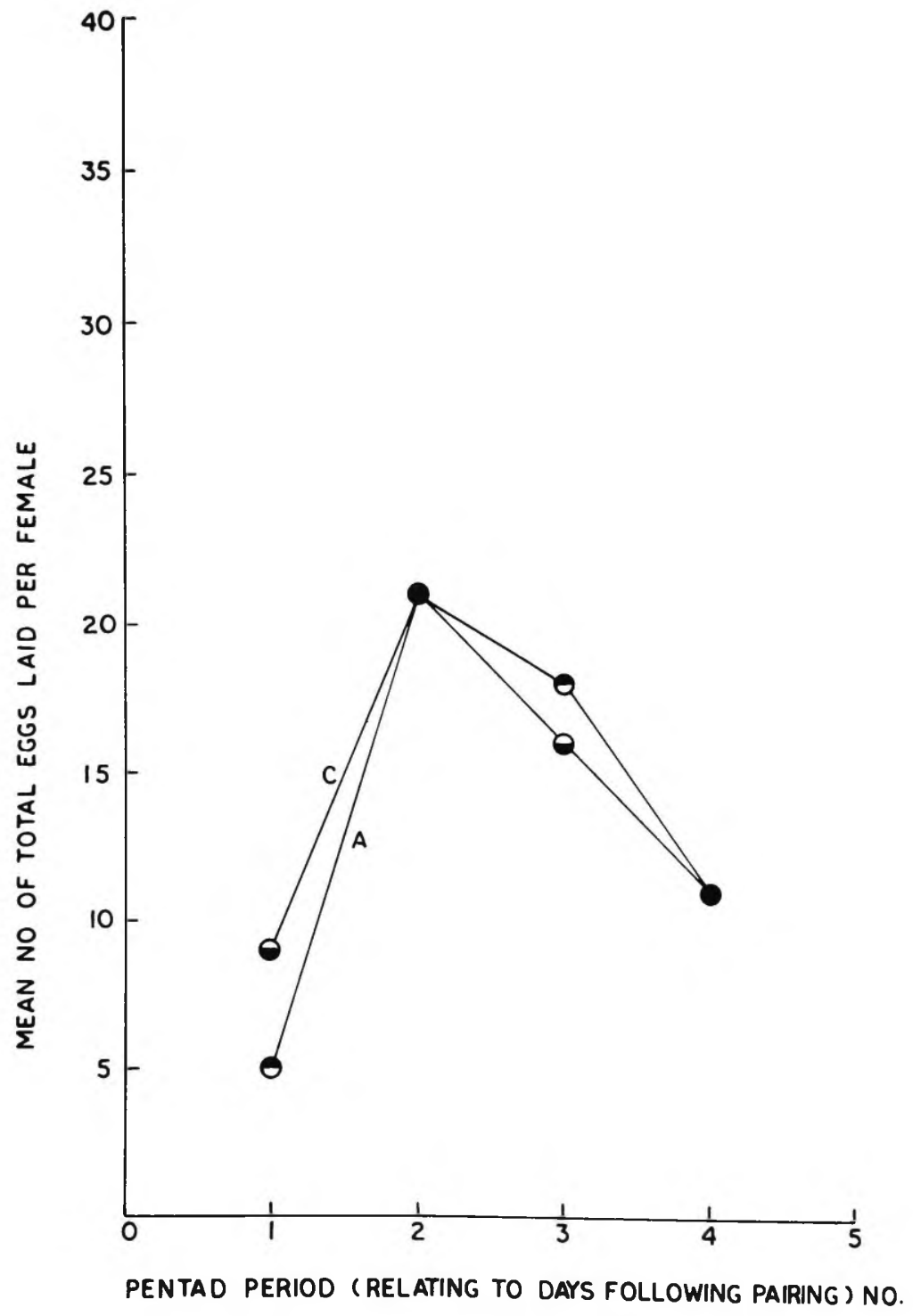

Fig. 1 - Ovipositional patterns in newborn females paired for mating with freshly ecloded males whose associations with the former were restricted to the first 5 days (A), or allowed to continue throughout the 20 day period (C) (Control) of the experiment (data for each series pooled from 5 females). 
less of the males being associated with their mated female partners only for the first 5 days or throughout the 20 - day period (control). This implies that continuation of the copulated male's association with its mated female subsequent to coitus has no special functional relevance, unlike in certain other phytophagous insects such as Corcyra cephalonica (KRISHNA \& NARAIN, 1976) and Earias fabia (SHAHI \& KRISHNA, 1978), in the oviposition of these tenebrionids.

Delaying for mating the exposure of the female, in relation to her age which in the present study varied from 4 to 20 days from emergence, to the newborn male (whose association with the female of any age was limited to the first 5 days of the experiment), however, produced interesting variations in the egg yield obtained from these beetles (PLATE I). In all situations, females laid more eggs (highest number recorded from 20 - day old individuals) during the lst I pentad in comparison to control insects. But occurrence of maximal egg laying during the 2nd pentad - a phenomenon manifested by newly eclosed females (Fig. 1) - was a feature noticed only in the cases of 4 and 9 - day old mateds (PLATE I, a \& b respectively). Females whose age advanced up to 15 or 20 days and got their first contact at this stage of their life with 0 - day old males for purposes of copulation deposited the highest number of eggs during the 3rd pentad (PLATE I, c \& $d$ respectively). Curiously enough, mean total egg output/female obtained at this point of the experimental time-scale from 15 - day old mated individuals coincided with that recosded for the first 5 day pericd from these insects. Subsequent ovipositional activity in terms of total egg yield, although interestingly shot up with respect to 4 (PLATE I, a) or 9 - day old (PLATE I, b) beetles, however, either remained static (15 - day old females which, amazingly, were the least productive all through) (PLATE I, c) or declined steeply (20 day old females) (PLATE I, d). Equally fascinating and diverse ovipositional trends were established by these beetles when the newborn females were paired with males belonging to different ages (PLATE II). Like in the previous set of experiments, a higher egg output was always noticed, in comparison to control, during the lst pentad. These beetles excepting females paired with 9 - day old males also gave higher egg yield values in the 4th pentad in contrast to data obtained for the same period from differently old females mated with freshly emerged males.

That the ovipositional activity in the reproductive physiology of T. castaneum appears to be regulated by an endogenously-based mechanism possessing an interestingly intricate operational relationship with age of males and females at the time of their mating is the main inference drawn from these observations.

There was cent per cent viability of eggs obtained from mated females involved in all the tests described here - a finding similar to that reported for eggs deposited by mateds of this species on different experimental regimens (SINGH \& KRISHNA, in press).

Data on the frequency of mating in these beetles during the lst and 2nd octets of a 16 - hour period selected for daily observation carried out for 10 days are schematically displayed in Figs. 2 \& 3 respectively. No copulation took place between a male and a female on the day of pai- 
A

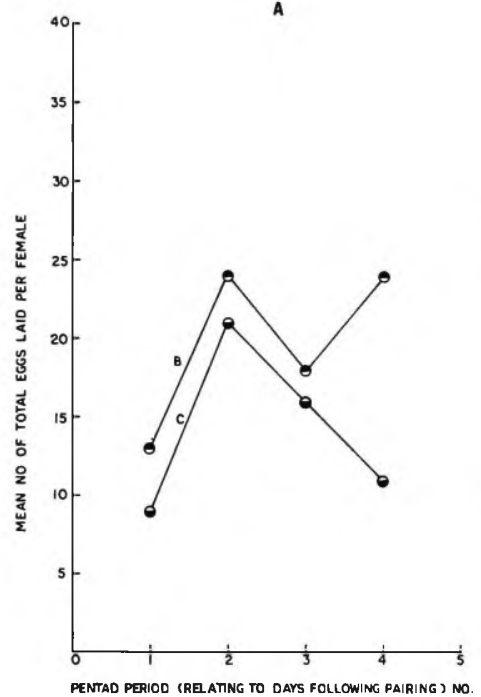

c

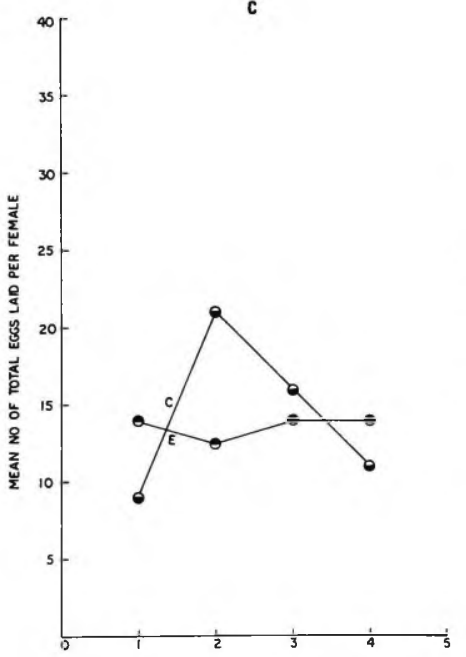

PENTAD PERIOD (RELATING TO DAYS FOLLOWING PAIRING) NO

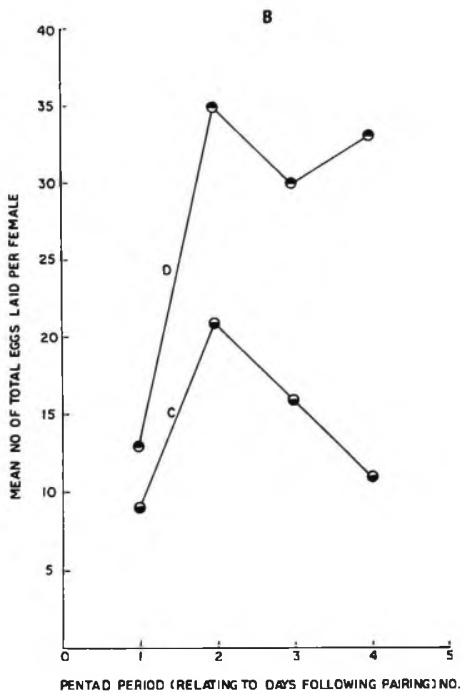

D

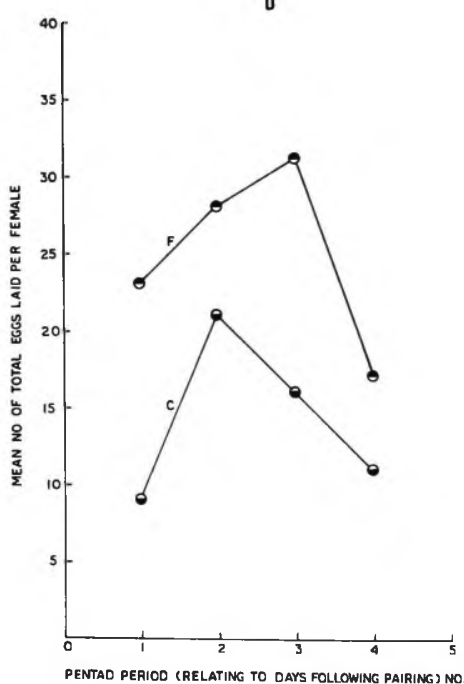

PLATE 1 - Ovipositional patterns between females at varying ages (expressed in days counted from emergence) (a. - B: 4; b. - D: 9; c. - E: 15; d. - F: 20) paired for mating with newborn males and those in vihich both sexes at the time of coupling for copulation were newly emerged individuals (C) (Control) (data for each series pooled from 5 females).

Note: Male's association with female (B, D, E and F) was limited to the first 5 days of the experiment. 


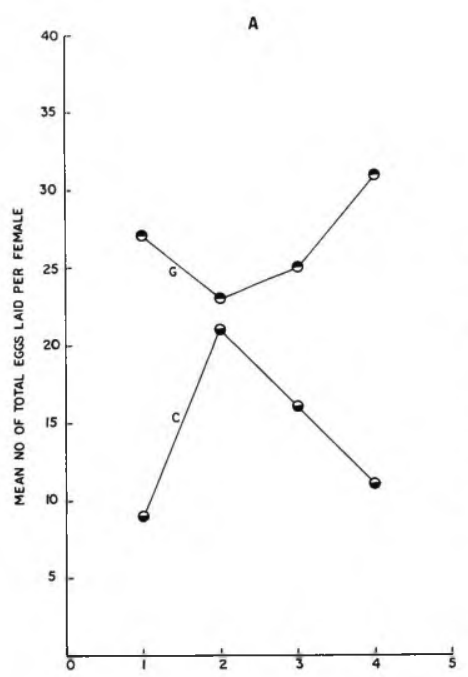

PENTAO PERIOd (helating to dAYs following pairing I NO.

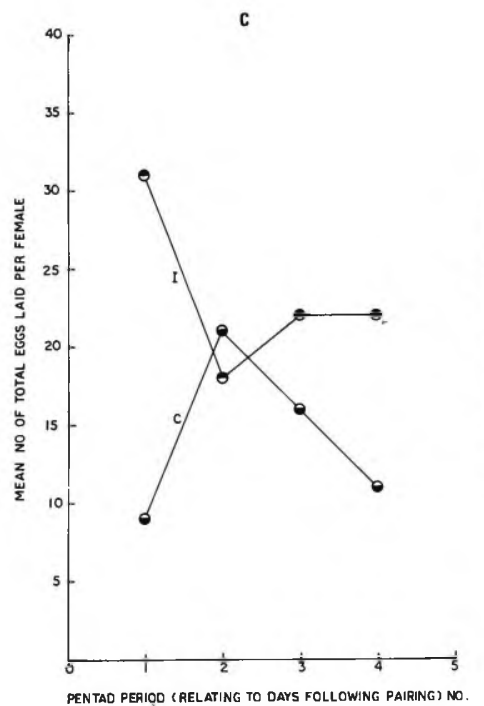

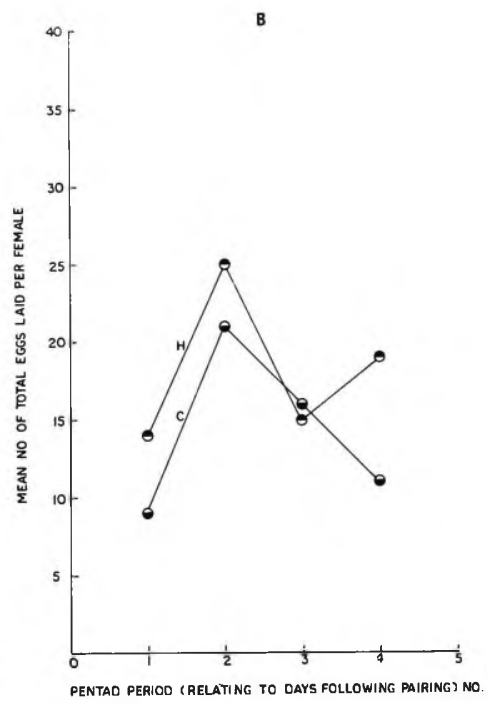

D

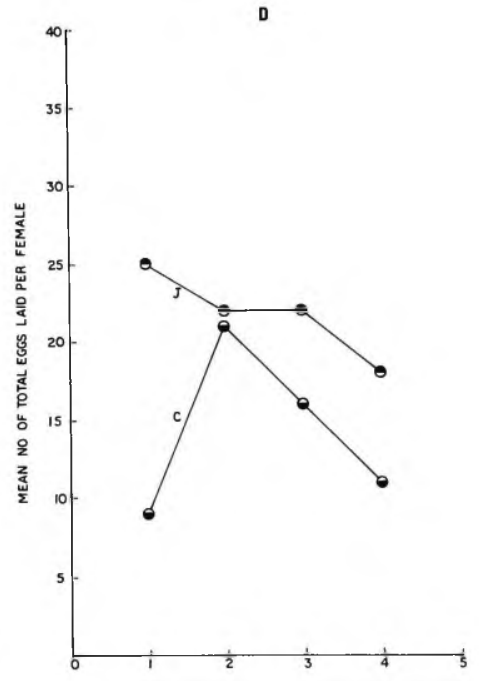

pentad period (aelating to days following paiRing) no.

PLATE || - Ovipositional patterns between newborn females paired with males of varying ages (expressed in days counted from emergence) (a. - G: 4 ; b. H: 9 ; c. $-\mathrm{I}: 15 ; \mathrm{d} .-\mathrm{J}: 20 \mathrm{l}$ for mating and those in which both sexes at the time of coupling for copulation were freshly eclosed individuals (C) (Control) (data for each series pooled from 5 females)

Note: Male's association with female in all cases except in Control as mentioned in PLATE I. 


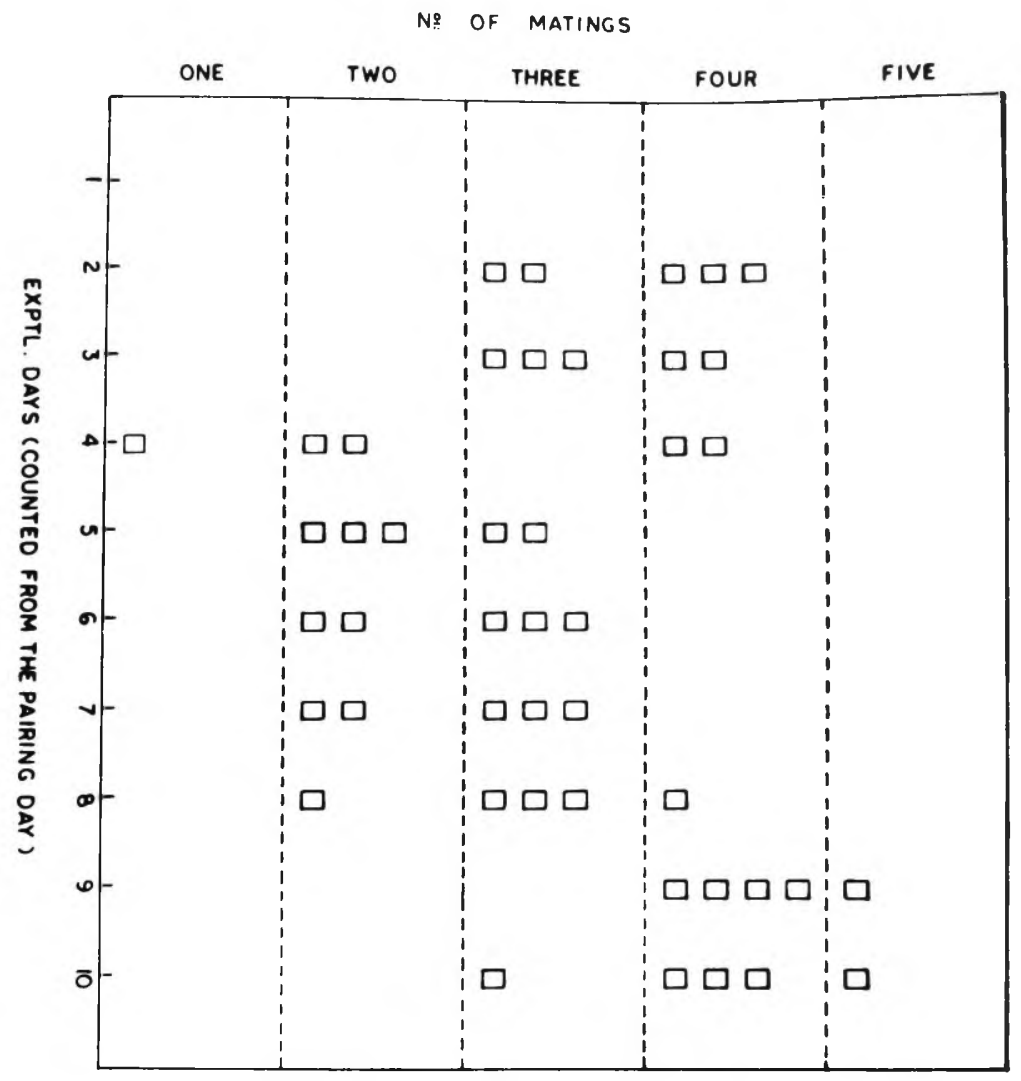

Fig. 2 - Schematic diagram showing the number of matings during the Ist octet between 5 separately arranged pairs of males and females.

Note: Each rectangular symbol within a segment in the diagram represents the datum concerning frequency of mating of a female individual on the specified day. Absence of a particular mating frequency datum for 1 or all 5 females tested on any day is indicated by omission of rectangular symbol(s) in appropriate segments in the diagram.

ring. But the two sexes began to mate within the lst octet of the experimental time on the day immediately following pairing and such sexual activity was consistently noticed in both octets on all the remaining 8 days of the test period. The number of matings between a male and a female ranged from 1 to 6 , a greater proportion of these pairs undergoing copulation 3 to 4 times like another stored products beetle, Trogoderma granarium (KARNAVAR, 1972) during either of the two octets. The duration of a single mating act between the two sexes in these pests was also very brief as in T. granarium (KARNAVAR, 1972); but it was limited either to 25 seconds or was extented up to a maximum of 208 seconds. Table 1 shows that, for each octet, varying proportions of matings between pairs possessed different temporal lengths. Majority of the coitus sessions in either of the octets lasted from 91 to 120 seconds. 


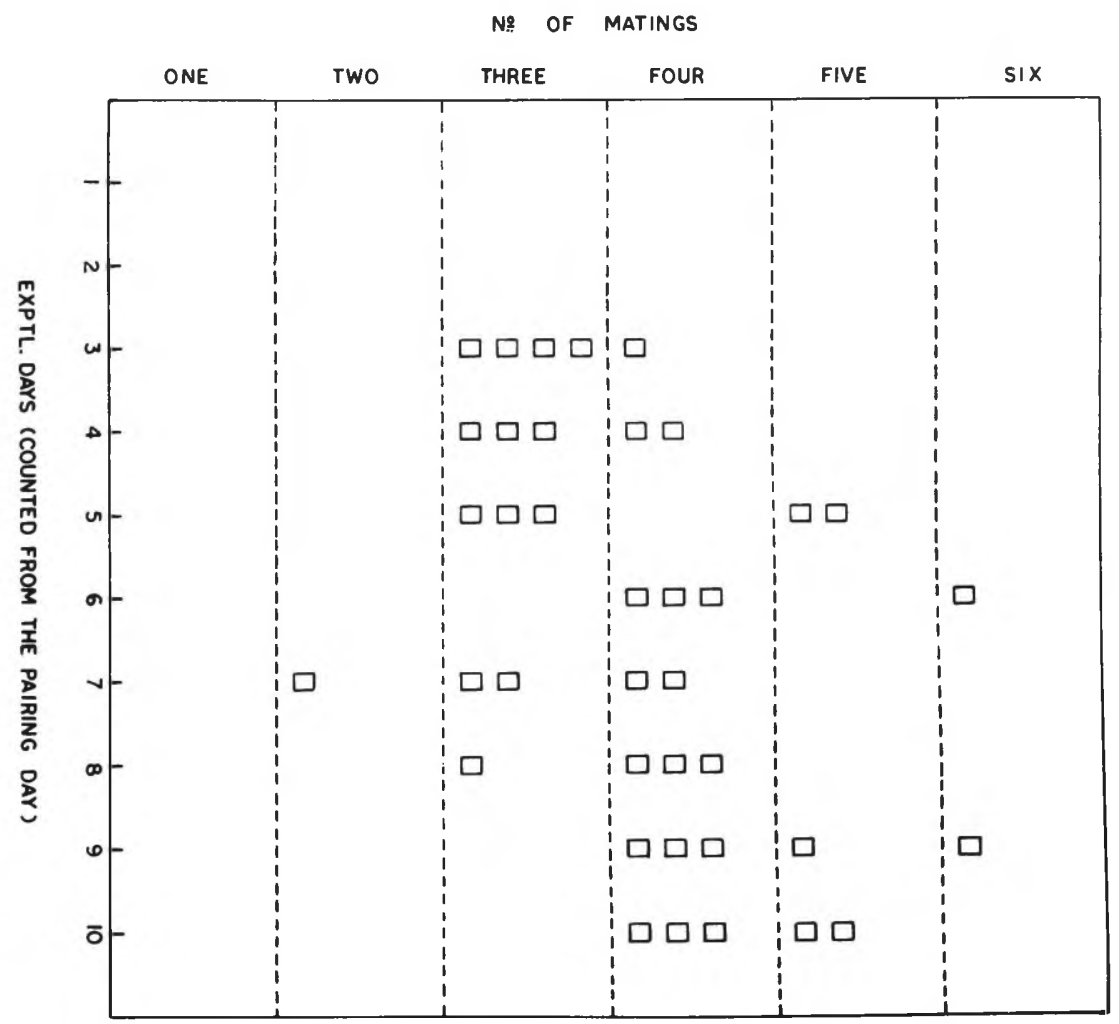

Fig. 3 - Schematic diagram showing the number of matings during the 2 nd octet between 5 separately arranged pairs of males and females.

Note: For explanation concerning rectangular symbols and their absence at certain places in the diagram see Fig. 2.

All these observations clearly indicate that in $\mathbf{T}$. castaneum, a male and a female, although they can effectuate multiple matings in both the octetss studied, they are inherently incapable of remaining in sexual union for prolonged periods notwithstanding provision of facility for these flour beetles to accomplish such a task associated with their reproductive activity. Evidently, these findings raise interesting questions concerning the not yet elucidated extrinsic and intrinsic conditions regulating the mating behavior, specially frequency and duration, of this insect pest.

\section{ACKNOWLEDGEMENT}

This work was supported by a research grant obtained from the University Grants Commission, New Delhi, India. 
Table 1: Frequency distribuition for length of mating period (given in range) in total matings between males and females of T. castaneum@.

\begin{tabular}{|c|c|c|c|c|c|c|c|c|}
\hline $\begin{array}{l}\text { Experimental } \\
\text { day (Counted } \\
\text { from pairing } \\
\text { day) }\end{array}$ & $\begin{array}{l}\text { Total } \\
\text { no. of } \\
\text { matings }\end{array}$ & $\begin{array}{l}1- \\
30\end{array}$ & $\begin{array}{c}\text { Length } \\
31- \\
60\end{array}$ & $\begin{array}{c}\text { of mat } \\
61- \\
90\end{array}$ & $\begin{array}{l}\text { ng } \\
91- \\
120\end{array}$ & $\begin{array}{c}\text { period } \\
121- \\
150\end{array}$ & $\begin{array}{c}\text { (in second } \\
151- \\
180\end{array}$ & $\begin{array}{l}\text { (s) } \\
181- \\
210\end{array}$ \\
\hline 1 & $\begin{array}{l}\mathbf{0} \\
\mathbf{0}\end{array}$ & $\begin{array}{l}\mathbf{0} \\
\mathbf{0}\end{array}$ & $\begin{array}{l}\mathbf{0} \\
\mathbf{0}\end{array}$ & $\begin{array}{l}\mathbf{0} \\
\mathbf{0}\end{array}$ & $\begin{array}{l}\mathbf{0} \\
\mathbf{0}\end{array}$ & $\begin{array}{l}\mathbf{0} \\
\mathbf{0}\end{array}$ & $\begin{array}{l}0 \\
0\end{array}$ & $\begin{array}{l}\mathbf{0} \\
0\end{array}$ \\
\hline 2 & $\begin{array}{r}18 \\
0\end{array}$ & $\begin{array}{l}2 \\
0\end{array}$ & $\begin{array}{l}6 \\
0\end{array}$ & $\begin{array}{l}4 \\
0\end{array}$ & $\begin{array}{l}5 \\
0\end{array}$ & $\begin{array}{l}1 \\
0\end{array}$ & $\begin{array}{l}\mathbf{0} \\
\mathbf{0}\end{array}$ & $\begin{array}{l}\mathbf{0} \\
\mathbf{0}\end{array}$ \\
\hline 3 & $\begin{array}{l}17 \\
16\end{array}$ & $\begin{array}{l}3 \\
1\end{array}$ & $\begin{array}{l}2 \\
6\end{array}$ & $\begin{array}{l}4 \\
2\end{array}$ & $\begin{array}{l}6 \\
6\end{array}$ & $\begin{array}{l}2 \\
1\end{array}$ & $\begin{array}{l}\mathbf{0} \\
\mathbf{0}\end{array}$ & $\begin{array}{l}\mathbf{0} \\
\mathbf{0}\end{array}$ \\
\hline 4 & $\begin{array}{l}13 \\
17\end{array}$ & $\begin{array}{l}1 \\
1\end{array}$ & $\begin{array}{l}1 \\
5\end{array}$ & $\begin{array}{l}3 \\
3\end{array}$ & $\begin{array}{l}6 \\
5\end{array}$ & $\begin{array}{l}2 \\
3\end{array}$ & $\begin{array}{l}\mathbf{0} \\
\mathbf{0}\end{array}$ & $\begin{array}{l}\mathbf{0} \\
\mathbf{0}\end{array}$ \\
\hline 5 & $\begin{array}{l}12 \\
19\end{array}$ & $\begin{array}{l}0 \\
2\end{array}$ & $\begin{array}{l}3 \\
8\end{array}$ & $\begin{array}{l}3 \\
2\end{array}$ & $\begin{array}{l}5 \\
6\end{array}$ & $\begin{array}{l}1 \\
1\end{array}$ & $\begin{array}{l}0 \\
0\end{array}$ & $\begin{array}{l}\mathbf{0} \\
\mathbf{0}\end{array}$ \\
\hline 6 & $\begin{array}{l}13 \\
18\end{array}$ & $\begin{array}{l}2 \\
0\end{array}$ & $\begin{array}{l}3 \\
3\end{array}$ & $\begin{array}{l}5 \\
4\end{array}$ & $\begin{array}{l}3 \\
3\end{array}$ & $\begin{array}{l}0 \\
4\end{array}$ & $\begin{array}{l}0 \\
2\end{array}$ & $\begin{array}{l}0 \\
2\end{array}$ \\
\hline 7 & $\begin{array}{l}13 \\
16\end{array}$ & $\begin{array}{l}0 \\
4\end{array}$ & $\begin{array}{l}4 \\
2\end{array}$ & $\begin{array}{l}1 \\
3\end{array}$ & $\begin{array}{l}7 \\
4\end{array}$ & $\begin{array}{l}1 \\
2\end{array}$ & $\begin{array}{l}\mathbf{0} \\
\mathbf{0}\end{array}$ & $\begin{array}{l}0 \\
1\end{array}$ \\
\hline 8 & $\begin{array}{l}15 \\
15\end{array}$ & $\begin{array}{l}3 \\
3\end{array}$ & $\begin{array}{l}2 \\
2\end{array}$ & $\begin{array}{l}4 \\
5\end{array}$ & $\begin{array}{l}6 \\
4\end{array}$ & $\begin{array}{l}0 \\
1\end{array}$ & $\begin{array}{l}\mathbf{0} \\
0\end{array}$ & $\begin{array}{l}\mathbf{0} \\
\mathbf{0}\end{array}$ \\
\hline 9 & $\begin{array}{l}21 \\
22\end{array}$ & $\begin{array}{l}3 \\
2\end{array}$ & $\begin{array}{l}1 \\
1\end{array}$ & $\begin{array}{l}5 \\
7\end{array}$ & $\begin{array}{r}12 \\
7\end{array}$ & $\begin{array}{l}0 \\
4\end{array}$ & $\begin{array}{l}\mathbf{0} \\
\mathbf{0}\end{array}$ & $\begin{array}{l}0 \\
1\end{array}$ \\
\hline 10 & $\begin{array}{l}21 \\
22\end{array}$ & $\begin{array}{l}2 \\
0\end{array}$ & $\begin{array}{l}3 \\
3\end{array}$ & $\begin{array}{l}6 \\
6\end{array}$ & $\begin{array}{l}7 \\
7\end{array}$ & $\begin{array}{l}3 \\
4 \\
\end{array}$ & $\begin{array}{l}0 \\
2\end{array}$ & $\begin{array}{l}0 \\
0\end{array}$ \\
\hline
\end{tabular}

@ Entire data based on observations collected from 10 mated pairs (5 tested during Ist octet and 5 tested during 2 nd octet), each pair constituting an independent replicate.

Note: (i) Upper number of each entry for each experimental day refers to mating (s) in the 5 pairs tested during the lst octet.

(ii) Lower number of each entry for each experimental day refers to mating (s) in the 5 pairs tested during the 2 nd octet. 


\section{LITERATURE CITED}

APPLEBAUM, S. W. \& Y. LUBIN, 1967 - The comparative effects of vitamin deficiency on development and on adult fecundity of Tribolium castaneum. Ent. exp. and appl. 10: 23-30.

BIRCH, L. C., T. PARK \& M. B. FRANK, 1951 - The effect of intraspecies and interspecies competition on the fecundity of two species of flour beetles. Evolution, 5: 116-132.

DAWSON, P. S. 1964 - Age at sexual rraturity in female flour beetles, Tribolium castaneum and T. confusum. Ann. Entomol. Soc. Amer. 57: 1-3.

ERDMAN, H. E. 1964 - Sexual precocity of the male flour beetle, Tribolium castaneum Herbst., and the influence of temperatures on reproduction during early adult life. Can. Ent. 96: 656-659.

GOOL, N. E. 1933 - Biology of the flour beetles, Tribolium confusum Duv. and Tribolium ferrugineum Fab. Jour. Agric. Res. 46: 327-334.

HAM $\angle L A I N E N$, M. K. \& S. R. LOSCHIAVO, 1977 - Effect of synthetic B-vitamin and natural enrichment of flour on larval development and fecundity of Tribolium conf usum and $T$. castaneum. Ent. exp. and appl. 21 : 29-37.

KARNAVAR, G. K. 1972 - Mating behaviour and fecundity in Trogoderma granarium (Coleoptera: Dermestidae) J. stored Prod. Res. 8: 65-69.

KHALIFA, A. \& A. BADAWY, 1955a - The effect of nutrition on the biology of Tribolium confusum Duv., Tribolium castaneun. Hbst., and Latheticus oryzae Waterh. (Coleoptera, Tenebrionidae). Bull. Soc. ent. Egypte, 39: 337-350.

KHALIFA, A. \& A. BADAWY, 1955b - Biolcgical studies on Tribolium confusum Duv., Tribolium castaneum Hbst., and Latheticus oryzae Waterh. (Coleoptera, Tenebrionidae). Bull. Soc. ent. Egypte, 39: 351-373.

KRISHNA, S. S. 1959 - Feeding behavior and utilisation of food in certain insect pests. Ph. D. thesis, pp. 186, Delhi University, Delhi, India.

PARK, T. \& M. B. DAVIS, 1945 - Further analysis of fecundity in the flour beetles Tribolium confusum Duval and Tribolium castaneum Herbst. Ann. Entomol. Soc. Amer. 38: 237-244.

SCHLAGER, G. 1960 - Sperm precedence in the fertilisation of eggs in Tribolium castaneum. Ann. Entomol. Soc. Amer. 53: 557-560.

SINGH, R. N. \& S. S. KRISHNA, in press - Effects of certain dietary regimes and exteroceptive factors associated with the developing pupa of Tribolium castaneum on the insect's reproductive programming. Mitt. zool. Mus. Berl. 57 (in press).

VARDELL, H. H. \& J. H. BROWER. 1976 - Sequential interspecific and intraspecific matings between Tribolium castaneum and $T$. confusum (Coleoptera Tenebrionidae): Effects on fecundity, egg fertility and number of progeny. Can. Ent. 108: 1391-1394. 
